\title{
Coob-Douglas production function on FDI in Southeast Europe
}

\author{
Asst. Professor of Business Administration \\ Mico Apostolov, $\mathrm{PhD}$ \\ UGD \\ Krste Misirkov b.b. P.O. Box 201 \\ 2000 Stip - Macedonia \\ Tel.: MKD +389 77848250 \\ | e-mail: mico.apostolov@ugd.edu.mk | \\ | home page: http://www.micoapostolov.com/ | \\ | UGD page: http://scholar.ugd.edu.mk/micoapostolov | \\ * Alumnus of Scuola Superiore Sant'Anna (Normale di Pisa), Pisa, Italia \\ * Alumnus of University of California, Berkeley - Haas School of Business, CA, USA \\ * Anciens du Collège d'Europe, Bruges/Natolin
}

\section{Abstract}

In this research we focus on effects of foreign direct investments in Southeast Europe economies. Using World Bank Microdata Library and specifically Enterprise Surveys we take a sample of six countries.

The model is based on firm-level data of a representative sample of economy's private sectors for Albania, Bosnia and Herzegovina, Croatia, Macedonia, Serbia and Slovenia. What we are closely examining are the effects of how foreign direct investments contribute to the development of domestic firms and the overall economy. Foreign direct investment is usually defined as dominant or controlling ownership of a company in one country, by an entity based in another country. Transition economies undergo a set of structural transformations intended to develop market-based institutions through economic liberalization, where prices are set by market forces. Hence, foreign direct investments remain main concern as major source of capital directed towards enterprise restructuring.

This research is build on Coob-Douglas production function where data are analyzed with econometric models, which as employed in this study examines the interrelationships between output and set of variables that influence foreign direct investments arrangements. Additionally, according to the results, estimates are specified on the ways foreign direct investments mold the economy.

JEL Classifications: D01; F21, G11; G31; L33; O11; P31

Keywords: FDI effects, output, Southeast Europe 